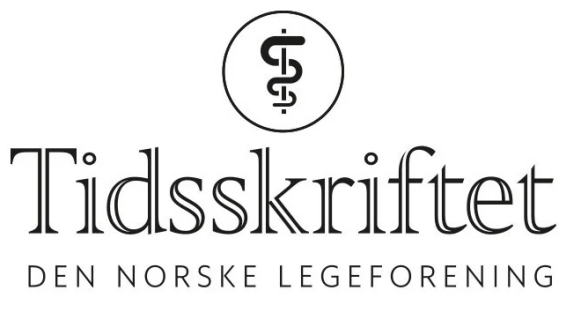

\title{
Enzymhemmer hindrer glutenindusert tarmskade
}

FRA ANDRE TIDSSKRIFTER

TORBJ ØRN ØYGARD SKODVIN

Tidsskriftet

Kan personer med cøliaki snart spise glutenholdig kost? En studie publisert i et av verdens høyest rangerte tidsskrifter gir håp om dette. Norske forskere er sentrale bidragsytere. 


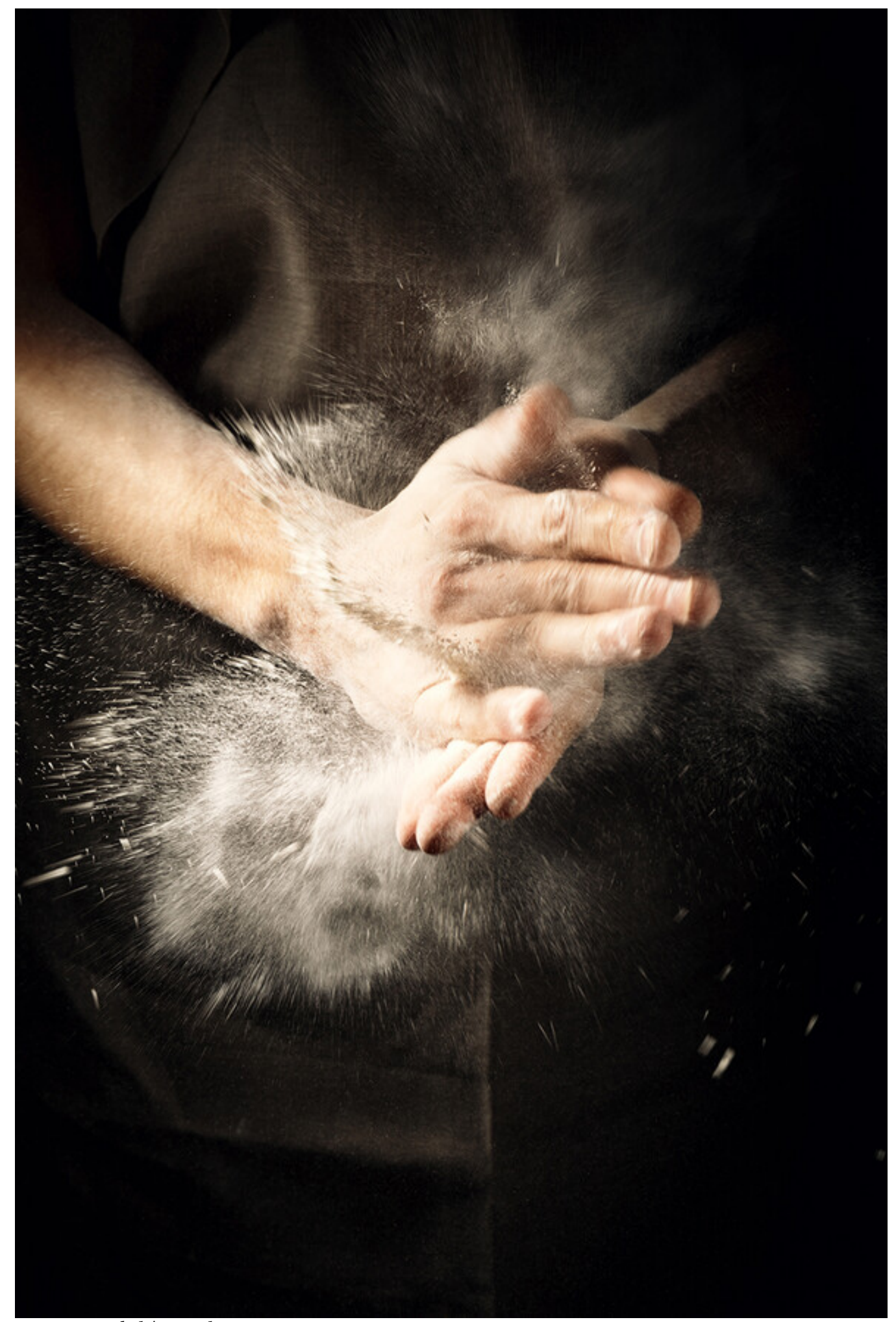

Foto: nerudol / iStock

- Forskningsgruppen vår har lenge vært ledende på cøliakifeltet. Nå har vi deltatt i en klinisk utprøving av et medikament som effektivt gjør at pasienter med cøliaki kan spise glutenholdig kost uten å få tarmskade. Dette sier Knut E. A. Lundin, som er nasjonal koordinator av en studie som nylig ble publisert i prestisjetunge New England Journal of Medicine (1). Lundin er professor og overlege ved Oslo universitetssykehus og forsker ved K.G. Jebsen-senter for cøliakiforskning. Han har forsket på cøliaki siden 198o-årene.

- Medikamentet vi har testet, er en selektiv hemmer av enzymet transglutaminase 2, som omdanner aminosyren glutamin til glutaminsyre i fragmenter av gluten. Disse

fragmentene kan da danne et kompleks med HLA-DQ2/DQ8, som så igjen gjenkjennes av T- 
celler i tarmen hos personer med cøliaki, slik at det blir vevsskade i tarmen, forklarer Lundin. Medikamentet gir en total hemming av transglutaminase 2. Effekten blir da den samme nesten uansett hvor stor glutenmengde man inntar.

Studien omfattet om lag 160 pasienter, som ble undersøkt med gastroskopi før oppstart. Deltagerne spiste en kjeks med 3 g gluten hver dag og ble randomisert i fire grupper. Tre grupper fikk henholdsvis $10 \mathrm{mg}$, $50 \mathrm{mg}$ og $100 \mathrm{mg}$ av medikamentet og den fjerde fikk placebo. Etter seks uker ble det gjort ny gastroskopi, der man målte ratio mellom høyde på tarmtottene mot dybde av kryptene i duodenal mucosa. For de tre gruppene som fikk medikamentet, var ratioen nærmest uendret, mens ratioen var redusert hos pasientene som fikk placebo. Bivirkninger var få og tilnærmet lik i alle fire gruppene.

Lundin startet med cøliakiforskning under sine doktorgradsstudier i 1986. Forskningsgruppen han tilhører, under ledelse av professor Ludvig M. Sollid, viste allerede i 1998 at deamidering av gluten er sentralt i patogenesen ved cøliaki (2). Da legemiddelselskapet Dr. Falk Pharma skulle gjennomføre utprøving av en peroral selektiv transglutaminase 2-hemmer, ble Lundin involvert sammen med to andre kliniske eksperter fra hhv. Finland og Tyskland. Fra Norge bidro Sykehuset Innlandet Gjøvik, Oslo universitetssykehus og Akershus universitetssykehus med til sammen 29 pasienter. Lundin fremhever spesielt overlegene Øistein Hovde, Jørgen Jahnsen og en rekke forskningssykepleiere som bidro med stor entusiasme.

Studien er en fase 2-studie, hvor terapeutisk effekt undersøkes hos et mindre antall pasienter. Forskerne har allerede planlagt en ny studie med omtrent 400 personer med cøliaki for å teste medikamentet på et større antall pasienter som til tross for glutenfri kost har vedvarende symptomer og totteforandringer.

- De samme tre sykehusene i Norge er involvert, men vi vil gjerne ha med flere norske sykehus, sier Lundin. Hvis den nye studien blir vellykket, kan medikamentet komme i bruk tidligst om 4-5 år, men sannsynligvis ikke så raskt, mener Lundin.

\section{LITTERATUR}

1. Schuppan D, Mäki M, Lundin KEA et al. A Randomized Trial of a Transglutaminase 2 Inhibitor for Celiac Disease. N Engl J Med 2021;385:35-45. [PubMed][CrossRef]

2. Molberg O, Mcadam SN, Körner R et al. Tissue transglutaminase selectively modifies gliadin peptides that are recognized by gut-derived T cells in celiac disease. Nat Med 1998; 4: 713-7. [PubMed] [CrossRef]

Publisert: 7. oktober 2021. Tidsskr Nor Legeforen. DOI: 10.4045/tidsskr.21.0566

(C) Tidsskrift for Den norske legeforening 2023. Lastet ned fra tidsskriftet.no 26. april 2023. 